\title{
Light on Scientific Diet for Medovriddhi or Overnutrition
}

\author{
Dr. Roshani Verma \\ M.D. Swasthavritta, Ayurveda Medical Officer, Pt. S.S. Govt. Ayurveda College and Hospital, Burhanpur, M.P, \\ India \\ *Corresponding Author: Dr. Roshani Verma, M.D. Swasthavritta, Ayurveda Medical Officer, Pt. S.S. \\ Govt. Ayurveda College and Hospital, Burhanpur, M.P, India
}

\begin{abstract}
The world is facing with many lifestyle disorders. These are being raised because of unbalanced highly refined food, sedentary lifestyle and stressful mental conditions. Over nutrition is a form of malnutrition in which the intake of nutrients exceeds the amount required for normal growth, development and metabolism. It can be of two type's obesity and oversupplying a specific nutrient. Obesity is one of the commonest lifestyle disorders. Obesity is a medical condition in which excess body fat has accumulated to the extent that it may have a negative effect on health. In India, obesity has reached epidemic proportions in the $21^{\text {st }}$ century with morbid obesity affecting 5\% of the total population. Complications related to obesity are hyperlipidemia, cardiovascular diseases, type two diabetes, osteoarthritis etc. Obesity reduces life expectancy and it is one of the leading preventable causes of death. In Ayurveda, this condition can be called as Medovriddhi, which is due to excess formation of Meda or fat, which accumulates in the body tissues. We have found that Samprapti indicates that Vata and Kapha Vriddhi leads to Medovriddhi. In Ayurvedic classical texts, there are many Ahara Dravyas like Jeeraka, Rajika, orange, plum, tomato etc. indicated for prevention as well as cure of these type of conditions and we have found that these food articles have proved anti obesity effect on animal models, human volunteers and isolated cell enzyme models with modern scientific parameters also. So, scientific diet is effective for management as well as prevention of obesity.
\end{abstract}

Keywords: Overnutrition, Obesity, Medovriddhi, Ahara Dravya

\section{INTRODUCTION}

The world is facing with many lifestyle disorders. These are being raised because of unbalanced highly refined food, sedentary lifestyle and stressful mental conditions. Over nutrition is a form of malnutrition in which the intake of nutrients exceeds the amount required for normal growth, development and metabolism. It can be of two type's obesity and oversupplying a specific nutrient. Obesity is one of the commonest lifestyle disorders. Obesity is a medical condition in which excess body fat has accumulated to the extent that it may have a negative effect on health. In India, obesity has reached epidemic proportions in the $21^{\text {st }}$ century with morbid obesity affecting $5 \%$ of the total population. Complications related to obesity are hyperlipidemia, cardiovascular diseases, type two diabetes, osteoarthritis etc. Obesity reduces life expectancy and it is one of the leading preventable causes of death. Indian Heart Association has been raising awareness about it. India has second highest obese children in the world, which is 14.4 million. Normal BMI $18.0-22.9 \mathrm{~kg} / \mathrm{m}^{2}$, Overweight $23.0-24.9 \mathrm{~kg} / \mathrm{m}^{2}$ and Obesity $>25 \mathrm{~kg} / \mathrm{m}^{2}$. According to Guidelines for diagnosis of obesity and abdominal obesity for India have been published in JAPI (2009) that a BMI over $23 \mathrm{~kg} / \mathrm{m}^{2}$ is considered overweight. In Ayurveda, this condition can be called as Medovriddhi, which is due to excess formation of Meda or fat, which accumulates in the body tissues. We have found that Samprapti indicates that Vata and Kapha Vriddhi leads to Medovriddhi. In Ayurvedic classical texts, there are many Ahara Dravyas like Jeeraka, Rajika, orange, plum, tomato etc. indicated for prevention as well as cure of these type of conditions and we have found that these food articles have proved anti obesity effect on animal models, human volunteers and isolated cell enzyme models with modern scientific parameters also. So, scientific diet is effective for the management as well as prevention of overnutrition.

\section{MATERIAL AND Method}

Samprapti of Medovriddhi or pathogenesis of overnutrition have been thoroughly studied and we have found that Medovriddhi or overnutrition is the condition developed by various factors like Vata and 
Kapha vitiation, lack of exercise, sedentary lifestyle, unbalanced food, Bija Dosha or genetic factors etc. In Ayurvedic classical texts, there are many Ahara Dravyas mentioned which can be helpful to reverse these conditions. We have studied various Ayurvedic classical texts to find out these food articles which acts on Medovriddhi and many online and printed journals to find out related researches of that particular food article on animal models, human volunteers and isolated cell enzyme models with modern scientific parameters and their role on overnutrition.

\section{RESUlT}

Properties of some food articles:

\begin{tabular}{|c|c|c|c|c|c|}
\hline Ahara Ahara & Rasa & Guna & Virya & Vipaka & Karma \\
\hline Dadima & $\begin{array}{l}\text { Kashaya, } \\
\text { Madhura, } \\
\text { Amla }\end{array}$ & $\begin{array}{l}\text { Laghu, } \\
\text { Snigdha }\end{array}$ & Ushna & $\begin{array}{l}\text { Madhural } \\
\text { Amla }\end{array}$ & $\begin{array}{l}\text { Tridoshahara, Hrdya, Shukrala, } \\
\text { Grahi }\end{array}$ \\
\hline Nimbuka & Amla, Katu & $\begin{array}{l}\text { Laghu, } \\
\text { Tikshna }\end{array}$ & Ushna & Amla & $\begin{array}{l}\text { Vata-kapha hara, Deepan- } \\
\text { pachana, Chakshushya }\end{array}$ \\
\hline Patol & Tikta, Katu & $\begin{array}{l}\text { Laghu, } \\
\text { Ruksha }\end{array}$ & Ushna & Katu & Kapha-pittahara \\
\hline Hingu & Katu & $\begin{array}{l}\text { Laghu, } \\
\text { Snigdha, } \\
\text { Tikshna }\end{array}$ & Ushna & Katu & $\begin{array}{lr}\text { Kapha-vatahara, } & \text { Hridya, } \\
\text { Aartavajanana, } & \text { Shulahara, } \\
\text { Chakshushya, } & \text { Bhedaniya, } \\
\text { Anulomaniya, Balya } & \\
\end{array}$ \\
\hline
\end{tabular}

Chemical constitution of some food articles:

\begin{tabular}{|l|l|l|l|}
\hline Ahara & Botanical name & Family & Chemical constituents \\
\hline Dadima & Punica granatum & Punicaceae & $\begin{array}{l}\text { Tannins, viz. punicalin, punicalagin etc., estrone, } \\
\text { punicic acid }\end{array}$ \\
\hline Nimbuka & Citrus medica & Rutaceae & $\begin{array}{l}\text { Abscisic acid, abscisin II, auxin, limonin, limonene, } \\
\text { poncirin }\end{array}$ \\
\hline Amalaki & $\begin{array}{l}\text { Phyllanthus } \\
\text { emblica }\end{array}$ & Euphorbiaceae & $\begin{array}{l}\text { Vit. C, phyllembin, linolic acid, indole acetic acid, } \\
\text { ayxubsm trigaloylglucose, terchebin, corilagin, ellagic } \\
\text { acid, phyllembic acid \& salts. }\end{array}$ \\
\hline Hingu & $\begin{array}{l}\text { Tricosanthes } \\
\text { dioica }\end{array}$ & Curcurbitaceae & $\begin{array}{l}\text { Nicotinic acid, riboflavin, vit. C, thiamine, 5- } \\
\text { hydroxytryptamine }\end{array}$ \\
\hline
\end{tabular}

Related researches of some food articles:

Amalaki:

- Sarvadoshaghna-Su. Su. 46

- Tridoshahara- Dh. Ni.

O Related researches:

$>$ Thakur \& Mandal-

- 5 groups of rabbits were studied for 16 weeks to determine the effect of emblica fruit and vit. C $(6 \mathrm{mg} / \mathrm{kg})$ on cholesterol induced hypercholesterolaemia and atherosclerosis. Both reduced the $\mathrm{s}$. cholesterol.

Yavani:

O Hridya- K. Ni., So. Ni.

- Vatahara

\section{O Related Researches:}

\section{$>$ In. J. Med. Res., 1986,83-}

When seed powder was fed (1\% mixed with powdered rabbit feed) for four weeks to normal albino rabbits hypocholesterolaemic, hypotriglyceridaemic and hypophspholipidaemic effect were observed from the first week itself. The S. cholesterol binding reserve and LDL levels, on the other hand, showed an increase in the HDL for corresponding periods. 
Rasona:

- Hridrogahara-Su.Su. 46, D.Ni., B.P.

- Vatakaphahara

O Related researches:

$>$ Bordia et al., 1973,1974-

- Garlic juice \& essential oil extract were found to have significant protective action against fatinduced increase in s. chol. \& plasma fibrinogen \& decrease in fibrinolytic activity as well as coagulation time.

$>$ Ind. J. Physiol. Pharmacol. 1969,23,1979-

- Significant decrease in all humans after 2 months of ingestion of garlic.

Here is a small description about these food articles, a lot of food articles are left.

\section{DISCUSSION}

Most of the spices and wholesome food articles augments the digestive fire leading to proper formation of the Rasadi Dhatus digest the Ama Dosha present at the Jatharagni level as well as the Dhatvagni level. Amla Rasa predominant fruits are Rasayana in nature which lead to formation of optimal Dhatus and protect the body from injury due to vitiated Doshas. These food articles proved cardio protective, anti obesity, antiatherosclerotic, anti inflammatory, anti hyperglycemic and anti oxidant properties etc.

\section{CONCLUSION}

Scientific diet for Medovriddhi or overnutrition proved beneficial in modern research parameters as well in this review study. More researches should be done in the field of Ayurvedic Pathya Ahara. It is easy to include beneficial food articles in diet in place of taking medicines for lifestyle diseases. These food articles not only beneficial in management but also helpful in prevention for development of these diseases. Efforts should be done for upgradation of Ahara Chikitsa in Swasthavritta branch of Ayurveda.

\section{REFERENCES}

[1] "India facing obesity epidemic: experts". The Hindu. 2007-10-12. "India facing obesity epidemic: experts" . The Hindu. 2007-10-12.

[2] Gulati, S; Misra, A (2017). "Abdominal obesity and type 2 diabetes in Asian Indians: Dietary strategies including edible oils, cooking practices and sugar intake". European Journal of Clinical Nutrition. 71 (7): 850-857.doi:10.1038/ejcn.2017.92 . PMID 28612831.

[3] Indian Heart Association Webpage 26April 2015. http://indianheartassociation.org/

[4] A study published in the New England Journal of Medicine.

[5] Misra, A; Chowbey, P; Makkar, B. M; Vikram, N. K; Wasir, J. S; Chadha, D; Joshi, S. R; Sadikot, S; Gupta, R; Gulati, S; Munjal, Y. P (2009). "Consensus statement for diagnosis of obesity, abdominal obesity and the metabolic syndrome for Asian Indians and recommendations for physical activity, medical and surgical management". The Journal of the Association of Physicians of India. 57: 163-70.PMID 19582986.

[6] Ayurveda literature.

Citation: R. Verma, "Light on Scientific Diet for Medovriddhi or Overnutrition", International Journal of Clinical Chemistry and Laboratory Medicine (IJCCLM), vol. 4, no. 1, pp. 6-8, 2018. http://dx.doi.org/10. 20431/2455-7153.0401002

Copyright: (1) 2018 Authors. This is an open-access article distributed under the terms of the Creative Commons Attribution License, which permits unrestricted use, distribution, and reproduction in any medium, provided the original author and source are credited. 